\title{
Effects of intraluminal acidification on oesophageal motor activity
}

\author{
I Bontempo, L Piretta, E Corazziari, F Michetti, F Anzini, A Torsoli
}

\begin{abstract}
This study assessed the effect of prolonged intraluminal acidification on the motor activity of the entire oesophageal body (under controlled conditions). Intraoesophageal pressures were recorded in 13 endoscopy negative subjects with gastro-oesophageal reflux disease in whom saline, $\mathrm{HCl} 0 \cdot 1 \mathrm{~N}$, and saline solutions were infused $(1.5 \mathrm{ml} / \mathrm{min})$ blindly in the oesophageal body, $6 \mathrm{~cm}$ distal to the upper oesophageal sphincter for three consecutive periods of 45 minutes each. These findings were compared with those of a control group. Intraoesophageal acidification caused an increase in the deglutition frequency $(p<0.02)$, the occurrence of multipeaked waves $(p<0.04)$ as well as a decrease of the propagating velocity $(p<0.04)$ of the primary peristaltic contractions. Furthermore, intraoesophageal acidification determined an increase, at all levels of the oesophagus, of the duration $(p<0.04)$ and, more noticeable in the proximal oesophageal body, of the amplitude $(\mathbf{p}<0.02)$ of primary peristaltic contraction waves. In conclusion prolonged intraoesophageal acidification can considerably affect frequency of deglutition, morphology, and propagating patterns of primary peristaltic contractions. This study shows that these effects are independent from volume distension of the oesophagus and supports the presence of acid sensitive receptors in the oesophageal mucosa.

(Gut 1994; 35: 884-890)
\end{abstract}

A variety of oesophageal motor abnormalities have been seen in patients affected by gastrooesophageal reflux. Some of them such as decreased mean lower oesophageal sphincter pressure and decreased mean amplitude of oesophageal contractions, have been regularly reported in gastro-oesophageal reflux patients, ${ }^{1-6}$ while others, such as increased amplitude, ${ }^{7}$ a change in morphology and propagating pattern ${ }^{8}$ of the oesophageal contractions, are controversial findings.

In the attempt to find out if, and to what extent, gastro-oesophageal reflux may affect the motor function of the oesophagus, several investigators have recorded the oesophageal motor activity during acid perfusion of the oesophagus but conflicting results have been reported. ${ }^{910}$ In these studies, however, oesophageal motor activity during acid per- fusion was not compared with equivalent control periods, the high infusion rates prevented discrimination of the effect of acidification from that of intraluminal distension and, with few exceptions, ${ }^{11}$ the acid infusion time was not standardised. In addition, only the motor activity of the distal oesophageal body has been assessed.

The aim of this study was to assess, under controlled conditions, the effect of prolonged intraluminal acidification on the motor activity of the entire oesophageal body.

\section{Subjects}

Nineteen subjects, seven men and 12 women, mean (SD) age 46 (10) years (age range 25-64) complaining of heartburn, retrosternal pain, or regurgitation, or all three for at least six months, were included in the study. In all the subjects, an upper gastrointestinal endoscopy excluded the presence of erosive/ ulcerative lesions of the oesophagus, stomach, and duodenum, and showed hyperaemia of the distal oesophagus in seven of them.

The study was approved by the ethical committee of the II Clinica Medica, Università La Sapienza, Rome and informed consent was obtained from each subject.

\section{Methods}

Intraluminal pressures were recorded by an eight lumen manometric catheter (Arndorfer Medical Specialities, Greendale, Wisconsin, USA; external diameter $7.0 \mathrm{~mm}$, each lumen internal diameter $1.5 \mathrm{~mm}$ ) with six side holes located $3 \mathrm{~cm}$ apart. Five of the longitudinally spaced side holes were continuously perfused with a low compliance pneumohydraulic infusion system (Arndorfer, Medical Specialities, Greendale, Wisconsin, USA) at a constant rate of $0.5 \mathrm{ml} / \mathrm{min}$.

The manometric probe was passed through the nose of fasting subjects in the supine position and located with its recording part within the stomach. It was then withdrawn by a stationary pull through technique and finally positioned throughout the entire study period with its proximal side hole at the level of the upper oesophageal sphincter.

Intraluminal pressure variations were recorded on a multichannel polygraph (Dynograph Recorder R 611, Anheim, CA, USA) with paper running at a constant rate of $1.0 \mathrm{~mm} / \mathrm{s}$. An intraluminal $\mathrm{pH}$ glass electrode (Beckman No 39042, Beckman Instruments Inc, Irvine, CA, USA) was used to measure intraoesophageal $\mathrm{pH}$. A reference electrode 


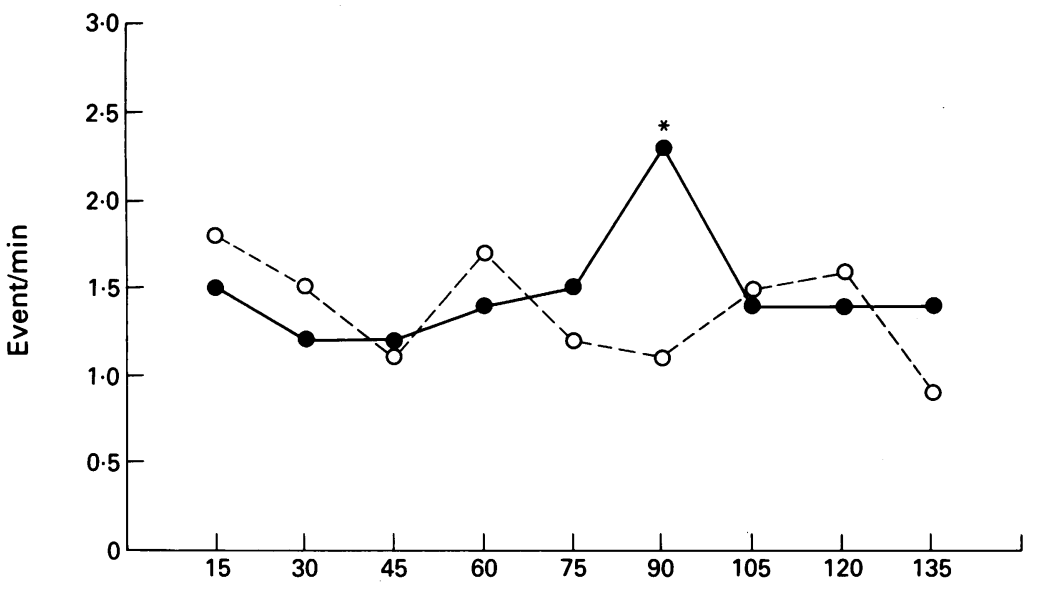

Time ( $\mathrm{min}$ )

Figure 1: Frequency of deglutition during the saline - $\mathrm{HCl}$-saline infusion sequence in the test group (solid line) and in the control group during saline infusion (dotted line). Median values are illustrated; ${ }^{\star} p<0.02 \mathrm{v}$ basal saline infusion, $p<0.05 \mathrm{v}$ equivalent time period during saline infusion in control patients.

(Beckman No 39168, Beckman Instruments Inc, Irvine, CA, USA) was kept immersed with two fingers in $\mathrm{KCl}$ saturated solution. The glass electrode was calibrated in standard buffer solution at $\mathrm{pH} 4$ and 7 before each examination. The $\mathrm{pH}$ electrode was located manometrically $5 \mathrm{~cm}$ proximal to the lower oesophageal sphincter.

Oesophageal pressures were recorded in 13 subjects (four men, nine women, mean age 43 (10) years) for three consecutive periods of 45 minutes during which isotonic saline, $\mathrm{HCl}$ $0 \cdot 1 \mathrm{~N}$ solution, and isotonic saline respectively, were infused at the constant rate of $1.5 \mathrm{ml} / \mathrm{min}$ through the side hole located $6 \mathrm{~cm}$ distal to the upper oesophageal sphincter. In the remaining six subjects (three men, three women, mean age 52 (8) years) only physiological saline solution was infused for three consecutive periods of 45 minutes.

Physiological saline and $\mathrm{HCl} 0 \cdot 1 \mathrm{~N}$ solutions were infused in a blind fashion. Before the study, all the patients were asked to report immediately the onset and the end of symptoms that might have presented during the study period. The patients could swallow freely during investigation, but during each 45 minute period they were asked to perform, at 20 second intervals, two series of 10 wet swallows (controlled primary peristalsis with ingestion of a $3 \mathrm{ml}$ water bolus), the first between the 12th and the 20th minute and the second between the 34 th and the 42 nd minute. If during saline infusion periods the intraoesophageal $\mathrm{pH}$ fell below $4 \cdot 0 \mathrm{U}$ the patients were asked to swallow one or more boluses of water $(10 \mathrm{ml})$ until the intraoesophageal $\mathrm{pH}$ reached $5.0 \mathrm{U}$ or above.

\section{ANALYSIS OF DATA}

The reported symptoms of heartburn, chest pain, and regurgitation were recorded on the manometric tracings by showing their respective onset and end.

Manometric tracings were divided into segments of equal length (45 minutes); each segment was coded, cut, and then evaluated blindly by an independent observer.

The frequency of the spontaneous acts of deglutition (event/min) was assessed by counting the number of the swallow related motor variations recorded by the sensor located in the upper oesophageal sphincter.

The following manometric variables recorded at $3,9,12$, and $15 \mathrm{~cm}$ distal to the upper oesophageal sphincter were evaluated: (1) the amplitude of spontaneous (dry) and controlled (wet) primary peristaltic contraction waves, measured from the mid inspiratory oesophageal pressure baseline to the wave peak; (2) the duration of spontaneous and controlled primary peristaltic contraction waves, measured as the time interval between the intersection of the rapid upward and downward pen deflection with the mean oesophageal pressure baseline; (3) morphology of the spontaneous and the controlled primary peristaltic contraction waves that were considered as single or multipeaked and non-repetitive or repetitive; (4) frequency of secondary peristalsis not induced by swallowing; (5) frequency of isolated and synchronous contractions waves.

The propagation velocity of spontaneous and controlled primary peristaltic contractions, measured from the first after swallow inhibition of the upper oesophageal sphincter to the onset of the peristaltic wave upstroke.

Only spontaneous swallows not preceded, for at least 12 seconds, by another swallow were evaluated and the data expressed as the median value, interquartile ranges, and ranges of 15 minute periods. Data of the controlled primary peristalsis were expressed as the median value, interquartile ranges, and ranges of each series of 10 swallows. Manometric values during spontaneous gastro-oesophageal reflux episodes (intraoesophageal $\mathrm{pH}<4.0 \mathrm{U}$ ) in the saline infusion period were excluded from the analysis.

Statistical analysis of data was performed at the end of the entire study. Within group changes in manometric variables were assessed with the Wilcoxon matched pairs signed rank test whereas the Mann-Whitney U test, two tailed probabilities, was used in the analysis of between group differences.

\section{Results}

\section{FREQUENCY OF DEGLUTITION}

The frequency of the spontaneous dry swallows did not vary significantly during the three consecutive 45 minute periods of saline infusion, the median value being 1.4 event $/ \mathrm{min}$ and the range $0.5-2.5$ event $/ \mathrm{min}$.

During the three consecutive 45 minute periods of the saline $-\mathrm{HCl}$ - saline infusion sequence, the median frequency of spontaneous dry swallows was $1 \cdot 3$ (range $0 \cdot 2-3 \cdot 8$ ), 1.6 (range $0 \cdot 4-4 \cdot 4$ ), and 1.4 (range $0 \cdot 1-4 \cdot 0$ ) event $/ \mathrm{min}$, respectively. The number of swallows showed an increment immediately after the onset of the oesophageal acidification, and increased progressively throughout the 
TABLE I Amplitude ( $m m \mathrm{Hg}$ ) of primary peristalsis waves after dry swallows

\begin{tabular}{|c|c|c|c|c|c|}
\hline \multirow{3}{*}{$\begin{array}{l}\text { cm from } \\
\text { upper oesophageal } \\
\text { sphincter }\end{array}$} & \multicolumn{5}{|l|}{ Solutions } \\
\hline & \multirow{2}{*}{$\begin{array}{l}\text { Saline } \\
(0-45 \text { min }) \dagger\end{array}$} & \multicolumn{3}{|l|}{$\mathrm{HCl}$} & \multirow{2}{*}{$\begin{array}{l}\text { Saline } \\
(0-45 \text { min }) \dagger\end{array}$} \\
\hline & & $0-15$ min & $16-30 \mathrm{~min}$ & $31-45 \min$ & \\
\hline \multicolumn{6}{|l|}{ Test group } \\
\hline 3 & $60 \cdot 5(37 \cdot 8-144 \cdot 3)$ & $79 \cdot 8(45 \cdot 2-150)^{\star}$ & $94 \cdot 6(43 \cdot 6-150 \cdot 2)^{\star}$ & $85.8(45.6-153.5)^{\star}$ & $77 \cdot 5(41.9-119 \cdot 5)$ \\
\hline 9 & $47.8(19.8-141.3)$ & $40 \cdot 4(24 \cdot 4-124 \cdot 4)$ & $52 \cdot 6(27-111 \cdot 1)$ & $58 \cdot 1(26 \cdot 8-96)$ & $56.5(28 \cdot 3-119 \cdot 1)$ \\
\hline 12 & $40 \cdot 7(24.5-140 \cdot 6)$ & $54 \cdot 8(26-108 \cdot 7)$ & $56(28 \cdot 4-110 \cdot 1)$ & $61 \cdot 2(36 \cdot 1-144 \cdot 7)$ & $65 \cdot 4(32-140)$ \\
\hline 15 & $62 \cdot 8(17 \cdot 8-159 \cdot 8)$ & $52 \cdot 3(20 \cdot 4-139 \cdot 4)$ & $58 \cdot 6(19 \cdot 3-149)$ & $67 \cdot 6(21 \cdot 9-137 \cdot 1)$ & $59 \cdot 3(25-133 \cdot 3)$ \\
\hline \multicolumn{6}{|l|}{ Control group } \\
\hline 3 & $56 \cdot 2(34 \cdot 5-98 \cdot 9)$ & $55 \cdot 4(36 \cdot 5-109)$ & $47 \cdot 4(32-93 \cdot 1)$ & $43 \cdot 8(14 \cdot 8-65 \cdot 1)$ & $50 \cdot 6(33-107 \cdot 1)$ \\
\hline 9 & $35 \cdot 5(20 \cdot 3-43 \cdot 2)$ & $38 \cdot 7(27 \cdot 5-46)$ & $34 \cdot 1(24 \cdot 7-53 \cdot 8)$ & $30 \cdot 8(18 \cdot 8-40)$ & $25 \cdot 3(20 \cdot 7-49 \cdot 5)$ \\
\hline 12 & $52 \cdot 8(28 \cdot 8-75 \cdot 8)$ & $39 \cdot 4(27 \cdot 7-68 \cdot 4)$ & $49 \cdot 8(23 \cdot 6-78)$ & $29 \cdot 7(21 \cdot 6-96)$ & $56 \cdot 8(26 \cdot 1-82 \cdot 3)$ \\
\hline 15 & $41 \cdot 8(18 \cdot 1-62 \cdot 1)$ & $40 \cdot 9(18.4-51 \cdot 39)$ & $34 \cdot 8(22 \cdot 9-59 \cdot 5)$ & $27 \cdot 9(13 \cdot 3-67 \cdot 5)$ & $28 \cdot 1(15 \cdot 1-109 \cdot 9)$ \\
\hline
\end{tabular}

${ }^{\star} \mathrm{p}<0.02 v$ basal saline and $v$ equivalent control time periods (medians and ranges). + Data of the 0-45 minute period are pooled together as there are no significant variations in the three 15 minute periods.

perfusion period; the increase of frequency during $\mathrm{HCl}$ infusion and the following decrease during saline infusion was statistically significant $(\mathrm{p}<0.02)$. Also the difference between the frequency during the last 15 minutes of $\mathrm{HCl}$ infusion (median 2.3 range $0 \cdot 6-4 \cdot 4)$ and the equivalent time period during saline infusion in the control patients was statistically significant $(\mathrm{p}<0 \cdot 05)$ (Fig 1). Frequency of swallows did not vary considerably between symptomatic and asymptomatic periods during $\mathrm{HCl}$ infusion.

\section{MANOMETRIC VARIABLES}

Only the manometric variables concerning primary peristaltis are reported because the low occurrence of secondary peristalsis, repetitive contractions or non-peristaltic contractions during both saline and $\mathrm{HCl}$ infusion, did not permit a proper statistical analysis to be carried out of these types of activity. None of the investigated manometric variables varied notably during the three consecutive 45 minute periods of saline infusion.

Amplitude - the amplitude of swallow induced contractions increased during $\mathrm{HCl}$ infusion at all oesophageal levels (Fig 2, Table I). This increment was statistically significant $v$ basal values after controlled $(\mathrm{p}<0.01$; Fig 2$)$ and spontaneous $(\mathrm{p}<0.02$; Table I) swallows at $3 \mathrm{~cm}$ from the upper oesophageal sphincter and $v$ equivalent time period of saline infusion in control subjects after controlled swallows at 9 and $15 \mathrm{~cm}$ from the upper oesophageal sphincter $(p<0 \cdot 02)$.

Duration - the duration of both controlled (Fig 3) and spontaneous (Table II) swallow induced contractions increased significantly during $\mathrm{HCl}$ infusion at all levels of the oesophagus $(p<0.05)$ and reverted towards basal values during the subsequent saline infusion (Fig 4).

Propagation velocity - the propagation velocity of both controlled and spontaneous (Table III) swallow induced contractions through the $15 \mathrm{~cm}$ oesophageal segment under study decreased significantly $(\mathrm{p}<0.04)$ during $\mathrm{HCl}$ infusion and then reverted towards basal values during the subsequent saline infusion $(\mathrm{p}<0.04)$ (Fig 4).

Morphology of contraction waves - a change in the morphology of peristaltic waves was apparent immediately after the onset of oesophageal acidification and then enhanced progressively throughout the acid perfusion period.

The percentage of single peaked spontaneous primary peristaltic contraction waves decreased at all levels of the oesophagus during the last 15 minutes of the $\mathrm{HCl}$ infusion period $(\mathrm{p}<0.04 v$ saline basal values and $\mathrm{p}<0.05 v$ the first 15 minutes of $\mathrm{HCl}$ infusion). This decrease of single peaked waves during $\mathrm{HCl}$ infusion reverted toward basal values during the subsequent period of saline infusion (Table IV).

TABLE II Duration (s) of primary peristalsis waves after dry swallows

\begin{tabular}{|c|c|c|c|c|c|}
\hline \multirow{3}{*}{$\begin{array}{l}\text { cm from } \\
\text { upper oesophageal } \\
\text { sphincter }\end{array}$} & \multicolumn{5}{|l|}{ Solutions } \\
\hline & \multirow{2}{*}{$\begin{array}{l}\text { Saline } \\
(0-45 \text { min }) \dagger\end{array}$} & \multicolumn{3}{|l|}{$\mathrm{HCl}$} & \multirow{2}{*}{$\begin{array}{l}\text { Saline } \\
(0-45 \mathrm{~min}) \dagger\end{array}$} \\
\hline & & $0-15$ min & $16-30 \mathrm{~min}$ & $31-45 \mathrm{~min}$ & \\
\hline \multicolumn{6}{|l|}{ Test group } \\
\hline $\begin{array}{r}3 \\
9 \\
12 \\
15\end{array}$ & $\begin{array}{l}2 \cdot 7(1 \cdot 8-3 \cdot 8) \\
5 \cdot 0(3-5 \cdot 9) \\
4 \cdot 7(3 \cdot 2-6 \cdot 7) \\
5 \cdot 0(33 \cdot 3-7 \cdot 1)\end{array}$ & $\begin{array}{l}3 \cdot 1(1 \cdot 6-4 \cdot 7)^{\star} \\
4 \cdot 6(2 \cdot 9-7) \ddagger \\
5 \cdot 1(2 \cdot 6-7) \ddagger \\
5 \cdot 0(2 \cdot 9-6) \ddagger\end{array}$ & $\begin{array}{l}4 \cdot 1(2 \cdot 1-5 \cdot 6) \star \star \\
5 \cdot 4(3 \cdot 1-8 \cdot 4) \oint \\
5 \cdot 7(3 \cdot 3-8 \cdot 9) \Uparrow \\
6 \cdot 1(3 \cdot 5-9 \cdot 7)^{b}\end{array}$ & $\begin{array}{l}4 \cdot 6(2 \cdot 2-7 \cdot 8)^{\star \star \star} \\
5 \cdot 9(3 \cdot 4-15 \cdot 4) \\
6 \cdot 7(3 \cdot 6-10 \cdot 2)^{\mathrm{a}} \\
7 \cdot 2(3 \cdot 9-17)^{\mathrm{c}}\end{array}$ & $\begin{array}{l}3 \cdot 1(1 \cdot 8-4 \cdot 8) \\
4 \cdot 6(3 \cdot 6-10 \cdot 5) \\
4 \cdot 6(3 \cdot 9-8 \cdot 4) \\
5 \cdot 8(4 \cdot 3-10 \cdot 1)\end{array}$ \\
\hline \multicolumn{6}{|l|}{ Control group } \\
\hline $\begin{array}{r}3 \\
9 \\
12 \\
15\end{array}$ & $\begin{array}{l}2 \cdot 9(2 \cdot 1-3 \cdot 9) \\
5 \cdot 0(3 \cdot 7-6 \cdot 3) \\
5 \cdot 7(4 \cdot 4-6 \cdot 4) \\
5 \cdot 5(4 \cdot 1-6 \cdot 8)\end{array}$ & $\begin{array}{l}3 \cdot 2(2-4 \cdot 2) \\
5 \cdot 1(4 \cdot 1-6 \cdot 0) \\
5 \cdot 0(4-5 \cdot 7) \\
5 \cdot 8(3 \cdot 5-6 \cdot 5)\end{array}$ & $\begin{array}{l}2 \cdot 5(2 \cdot 5-3 \cdot 9) \\
4 \cdot 9(3 \cdot 8-7 \cdot 4) \\
4 \cdot 3(3 \cdot 5-7 \cdot 2) \\
5 \cdot 7(4-8 \cdot 2)\end{array}$ & $\begin{array}{l}3 \cdot 0(2 \cdot 1-3 \cdot 6) \\
5 \cdot 5(3 \cdot 9-6 \cdot 8) \\
5 \cdot 5(3 \cdot 6-6 \cdot 9) \\
5 \cdot 3(4-7 \cdot 2)\end{array}$ & $\begin{array}{l}2 \cdot 8(1 \cdot 6-3 \cdot 8) \\
4 \cdot 1(3 \cdot 2-5 \cdot 8) \\
4 \cdot 5(3 \cdot 5-6 \cdot 7) \\
5 \cdot 3(4 \cdot 4-7 \cdot 3)\end{array}$ \\
\hline
\end{tabular}

$\dagger$ Data of the $0-45$ minute period are pooled together as there are no significant variations in the three 15 minute periods. ${ }^{\star} \mathrm{p}<0.04 v$ basal saline infusion, $\mathrm{p}<0.01 v 16-30$ minute and $v 31-45$ minute $\mathrm{HCl}$ periods; ${ }^{\star \star} \mathrm{p}<0.01 v$ basal saline, $\mathrm{p}<0.04 v$ 31-45 minute $\mathrm{HCl}$ period, $\mathrm{p}<0.03 v$ subsequent saline infusion, $\mathrm{p}<0.02 v 16-30$ minute control period; ${ }^{\star \star} \mathrm{p}<0.01 v$ basal saline and $v$ subsequent saline, $\mathrm{p}<0.02 v 31-45$ minute control period; $\neq \mathrm{p}<0.01 v 16-45$ minute $\mathrm{HCl}$ period; ( $\mathrm{p}<0.04 v$ basal saline; $\mathrm{p}<0.02 v$ basal saline, $\mathrm{p}<0.04 v$ subsequent saline; $\uparrow \mathrm{p}<0.03 v$ basal saline, $\mathrm{p}<0.01 v 31-45$ minute $\mathrm{HCl}$ period, $\mathrm{p}<0.05$ $v 16-30$ minute control period; ${ }^{\mathrm{a}} \mathrm{p}<0.01 v$ basal saline, $\mathrm{p}<0.02 v$ subsequent saline; ${ }^{\mathrm{b}} \mathrm{p}<0.01 v$ basal saline, $\mathrm{p}<0.01 v 31-45$ minute $\mathrm{HCl}$ period; ${ }^{\mathrm{p}} \mathrm{p}<0.01 v$ basal saline, $\mathrm{p}<0.01 v$ subsequent saline, $\mathrm{p}<0.01 v 31-45$ minute control period (medians and ranges). 
Figure 2: Amplitude of primary peristaltic contraction waves after controlled wet swallows, measured at 3, 9, 12, and $15 \mathrm{~cm}$ from the upper oesophageal sphincter (UOS). $\mathrm{HCl} \mathrm{1,} \mathrm{HCl} 2$, Sal, Sal show the series of controlled swallows during $\mathrm{HCl}$ and saline infusion, respectively. Values of saline infusions represent the two series of controlled swallows. Median values and interquartile ranges are illustrated. Filled columns: test patients; empty columns: control patients. ${ }^{\star} p<0.01 \mathrm{v}$ basal saline infusion; ${ }^{\star \star} \mathrm{p}<0.02 \mathrm{v}$ equivalent time period of saline infusion in control subjects.
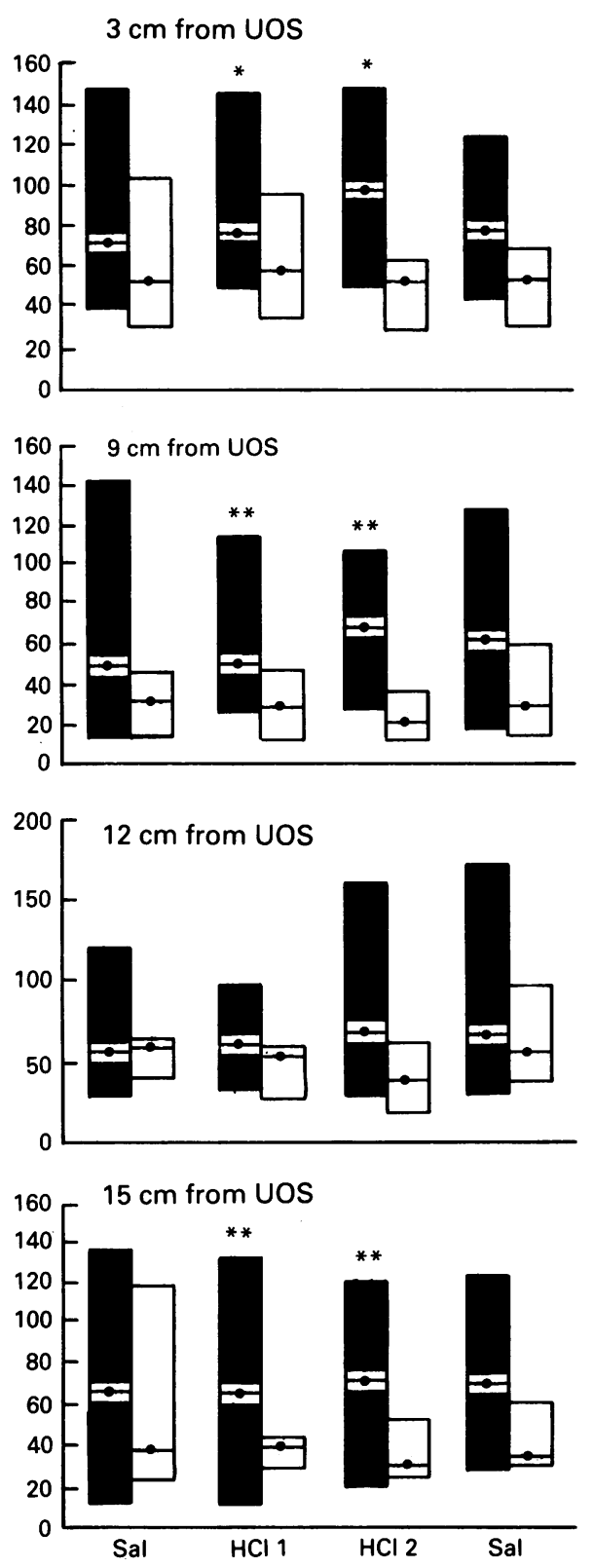

The percentage of single peaked controlled primary peristaltic contraction waves decreased to a large extent during $\mathrm{HCl}$ infusion in the second series of wet swallows only at 12 and $15 \mathrm{~cm}$ from the upper oesophageal sphincter $(\mathrm{p}<0.04 \quad v$ saline basal values and $\mathrm{p}<0.03 v$ the first series of wet swallows during $\mathrm{HCl}$ infusion) (Figs 4 and 5).

ASYMPTOMATIC AND SYMPTOMATIC PERIODS Only two subjects of the control group complained of symptoms (heartburn and regurgitation) during the three consecutive 45 minute periods of saline infusion. Of the subjects given the saline - $\mathrm{HCl}$ - saline infusion sequence, two reported symptoms (heartburn and regurgitation) during the basal saline infusion, seven reported symptoms (heartburn, regurgitation, and chest pain) during the first 15 minutes, and 12 during the second and third 15 minutes of $\mathrm{HCl}$ infusion; in 10 of them, symptoms disappeared during the subsequent saline infusion period. Only one subject experienced no symptoms during the entire study.

No statistically significant difference was found when comparing the investigated variables of the asymptomatic $v$ symptomatic periods during $\mathrm{HCl}$ infusion.

\section{Discussion}

This study shows that the frequency of deglutitions increases progressively during oesophageal acidification. A similar finding was reported in a previous study after an acid bolus, as small as $2.5 \mathrm{ml}$, was introduced into the oesophagus of healthy subjects. ${ }^{12}$ The number of swallows did not vary in the control group during saline infusion, and reverted to basal values immediately after the acid infusion was stopped in the test group. These findings show that the increase in the frequency of swallowing is related to a low intraluminal $\mathrm{pH}$ value, independent of intraoesophageal distension by the instilled liquid, and is related to the time of oesophageal acidification.

It is possible to hypothesise that mucosal acidification in itself can activate the act of swallowing through a reflex mechanism; alternatively, mucosal acidification may, by a reflex mechanism, enhance salivary secretion and thus increase the frequency of swallowing.

The acid induced increase of the deglutitive acts was accompanied by a parallel increase of primary peristaltic contractions.

TABLE III Propagation velocity $(\mathrm{cm} / \mathrm{s})$ of primary peristalsis

\begin{tabular}{|c|c|c|c|c|c|}
\hline \multirow[t]{3}{*}{ Dry swallows } & \multicolumn{5}{|l|}{ Solutions } \\
\hline & \multirow{2}{*}{$\begin{array}{l}\text { Saline } \\
(0-45 \text { min }) \dagger\end{array}$} & \multicolumn{3}{|l|}{$\mathrm{HCl}$ or saline } & \multirow{2}{*}{$\begin{array}{l}\text { Saline } \\
(0-45 \text { min }) \dagger\end{array}$} \\
\hline & & $0-15 \mathrm{~min}$ & $16-30 \mathrm{~min}$ & $31-45$ min & \\
\hline $\begin{array}{l}\text { Test Group } \\
\text { Control group }\end{array}$ & $\begin{array}{l}3 \cdot 7(2 \cdot 5-5 \cdot 2) \\
3 \cdot 8(2 \cdot 8-5 \cdot 6)\end{array}$ & $\begin{array}{l}3 \cdot 1(2 \cdot 6-4 \cdot 7) \ddagger \\
3 \cdot 6(2 \cdot 7-5 \cdot 1)\end{array}$ & $\begin{array}{l}3 \cdot 1(1 \cdot 8-5 \cdot 4) \\
4 \cdot 1(3 \cdot 0-5 \cdot 3)\end{array}$ & $\begin{array}{l}2 \cdot 5(1 \cdot 4-3 \cdot 9) \\
3 \cdot 6(2 \cdot 7-5 \cdot 2)\end{array}$ & $\begin{array}{l}3 \cdot 5(2 \cdot 8-5 \cdot 0) \\
3 \cdot 8(2 \cdot 7-6 \cdot 3)\end{array}$ \\
\hline \multirow[t]{3}{*}{ Wet Swallows } & \multicolumn{5}{|l|}{ Solutions } \\
\hline & \multirow{2}{*}{$\begin{array}{l}\text { Saline } \\
\text { (1st and 2nd series) }\end{array}$} & \multicolumn{3}{|l|}{$\mathrm{HCl}$ or saline } & \multirow{2}{*}{$\begin{array}{l}\text { Saline } \\
\text { (1st and } 2 \text { nd series) }\end{array}$} \\
\hline & & 1 st series & & & \\
\hline $\begin{array}{l}\text { Test group } \\
\text { Control group }\end{array}$ & $\begin{array}{l}3 \cdot 5(2 \cdot 6-4 \cdot 2) \\
3 \cdot 6(2 \cdot 8-5 \cdot 4)\end{array}$ & $\begin{array}{l}3 \cdot 1(2 \cdot 0-3 \cdot 8)^{\star} \\
3 \cdot 5(2 \cdot 7-5 \cdot 2)\end{array}$ & & $\begin{array}{l}\cdot 6)^{\star \star} \\
\cdot 4)^{\star}\end{array}$ & $\begin{array}{l}3 \cdot 2(2 \cdot 7-4 \cdot 3) \\
3 \cdot 3(2 \cdot 7-4 \cdot 3)\end{array}$ \\
\hline
\end{tabular}

†Data of the 0-45 minute period are pooled together as there are no significant variations in the three 15 minute periods. $\neq \mathrm{p}<0.04 v$ basal saline, $\mathrm{p}<0.05 v 31-45$ minute $\mathrm{HCl}$ periods; $\mathrm{Sp}<0.01 v$ basal saline and $v 16-30$ minute control period; $\mathrm{p}<0.01$ $v$ basal saline, $v$ subsequent saline, and $v 31-45$ minute control period; ${ }^{\star} \mathrm{p}<0.02 v$ basal saline, $\mathrm{p}<0.05 v 2$ nd series; ${ }^{\star \star} \mathrm{p}<0.01 v$ basal saline and $v$ subsequent saline (medians and ranges). 
Figure 3: Duration of primary peristaltic contraction waves after controlled wet swallows measured at 3, 9, 12, and $15 \mathrm{~cm}$ from the upper oesophageal sphincter (UOS). $\mathrm{HCl} 1, \mathrm{HCl} 2$, Sal, Sal show the series of controlled swallows during $\mathrm{HCl}$ and saline infusion, respectively. Values of saline infusions represent the two series of controlled swallows. Median values and interquartile ranges are illustrated. Filled columns: test patients; empty columns: control patients. ${ }^{\star} p<0.05 \mathrm{v}$ basal saline infusion, $p<0.01 \mathrm{v}$ subsequent saline infusion, $p<0.05 \mathrm{v}$ equivalent time period in control group; $\star \star p<0.03 \mathrm{v}$ basal saline infusion, $p<0.05 \mathrm{v}$ equivalent time period in control group; $\dagger p<0.03 \mathrm{v}$ basal saline infusion, $p<0.01 \mathrm{v} 1$ st series during $\mathrm{HCl} ; \ddagger p<0.01 \mathrm{v}$ basal saline infusion.
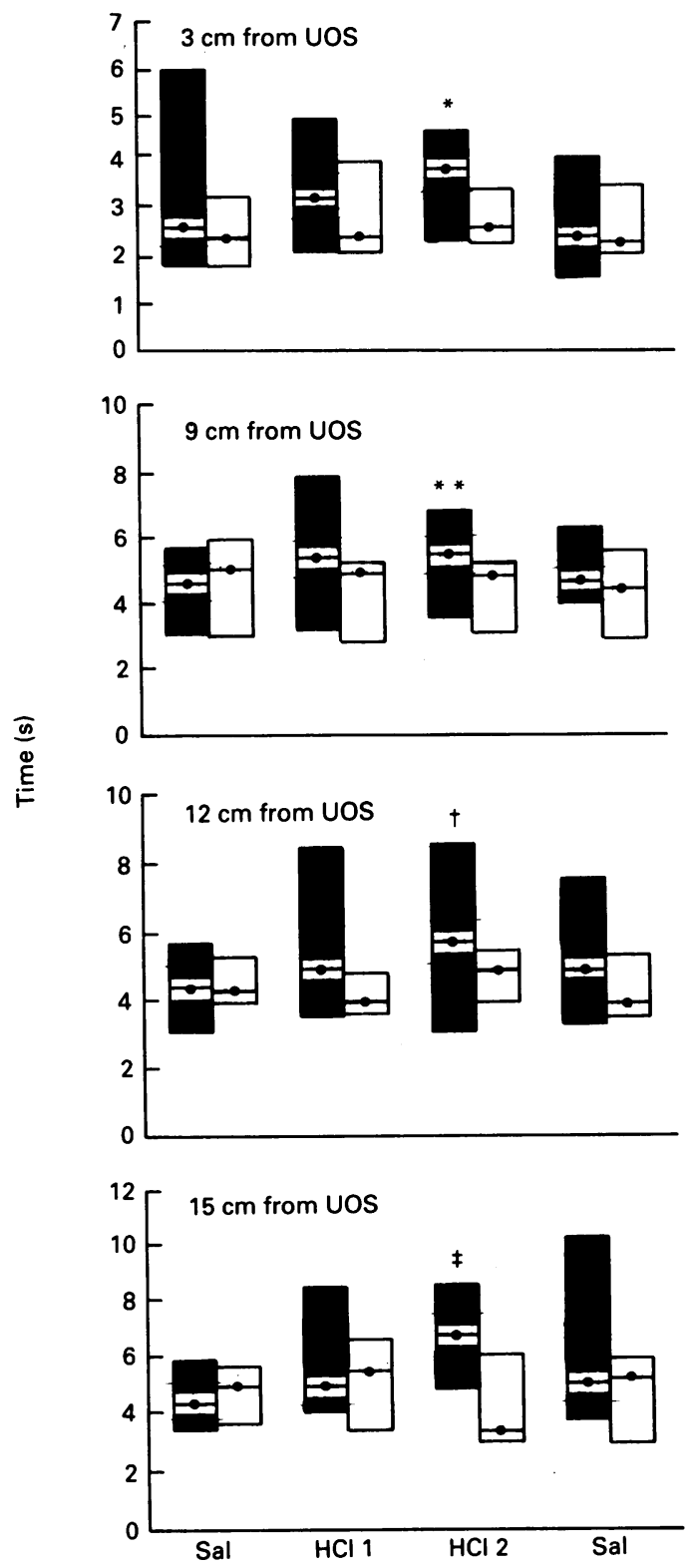

Secondary peristalsis, simultaneous and repetitive contractions were detected only occasionally during control saline infusion, and their comparative occurrence did not vary during the acid perfusion period. This finding is not surprising because of the slow perfusion rate used in this study, whereas secondary peristalsis and simultaneous contractions are elicited in both normal subjects ${ }^{13}$ and reflux patients $^{14}$ by a mean intraoesophageal fluid volume of $16 \mathrm{ml}$.

The manometric morphology of primary peristalsis, which was represented to a large extent by single peaked waves during saline infusion, changed to include numerous multipeaked waves during intraoesophageal acidification, and reverted to basal conditions after discontinuation of acid perfusion.

These findings show that oesophageal acidification may cause a change in the motor patterns of primary peristaltic contractions. These motor abnormalities seem to be secondary to the intraluminal acidification, and independent from the effect of the volume distension of the oesophageal body as well as from the increase of the deglutitive acts as a change in wave morphology was present after controlled wet swallows. Spontaneous dry swallows occurring at less than 12 second intervals were excluded from the analysis.

This study shows that during acidification both wet and dry primary peristaltic contractions show an increase in duration at all levels of the oesophagus. An increase in amplitude of the peristaltic contractions during acidification also occurred and was more evident in the upper third of the oesophagus. Finally, peristaltic contractions show a decrease in propagation velocity during acidification.

The morphology of peristaltic waves did not vary in the control group during saline infusion but its change started immediately after the onset of oesophageal acidification, and increased progressively throughout the acid perfusion period, also showing the tendency to revert toward basal conditions after acid infusion had finished. This time related response may explain why a similar finding was not seen previously during short term oesophageal acidification. ${ }^{15}$ An increased duration as well as a decreased propagation velocity of peristaltic contraction has been seen at the level of the distal oesophageal body ${ }^{9} 1617$ during intraluminal acidification with higher perfusion rates (at least $5 \mathrm{ml} / \mathrm{min}$ ). In the absence, however, of a comparable control infusion these changes in the peristaltic contractions have been interpreted as a response to intraluminal fluid distension. ${ }^{9}$

This study shows that the changes in primary peristalsis during oesophageal

TABLE IV Morphology of primary peristalsis (percentage of single peaked waves after dry swallows)

\begin{tabular}{|c|c|c|c|c|c|}
\hline \multirow{3}{*}{$\begin{array}{l}\text { cm from } \\
\text { upper oesophageal } \\
\text { sphincter }\end{array}$} & \multicolumn{5}{|l|}{ Solutions } \\
\hline & \multirow{2}{*}{$\begin{array}{l}\text { Saline } \\
(0-45 \text { min }) \dagger\end{array}$} & \multicolumn{3}{|l|}{$\mathrm{HCl}$} & \multirow{2}{*}{$\begin{array}{l}\text { Saline } \\
(0-45 \mathrm{~min}) \dagger\end{array}$} \\
\hline & & $0-15 \min$ & $16-30 \mathrm{~min}$ & $31-45 \min$ & \\
\hline $\begin{array}{l}\text { Test group } \\
3 \\
9 \\
12 \\
15\end{array}$ & $\begin{array}{l}97(81-100) \\
79 \cdot 3(41 \cdot 7-100) \\
77 \cdot 9(50 \cdot 1-100) \\
70 \cdot 8(47 \cdot 8-100)\end{array}$ & $\begin{array}{c}100(66 \cdot 7-100) \\
79 \cdot 6(45 \cdot 5-100) \\
90(26 \cdot 7-100) \\
70(33 \cdot 3-100)\end{array}$ & $\begin{array}{l}91 \cdot 2(42 \cdot 3-100) \\
59 \cdot 3(33 \cdot 3-100) \\
60(4 \cdot 3-100) \\
60 \cdot 4(5 \cdot 3-92 \cdot 9)\end{array}$ & $\begin{array}{l}81 \cdot 8(20-100)^{\star} \\
66 \cdot 7(18 \cdot 2-87 \cdot 5)^{\star \star} \\
60(26 \cdot 9-100)^{\star} \\
50(5 \cdot 6-75)^{\star \star}\end{array}$ & $\begin{array}{l}100(88-100) \\
67(21 \cdot 3-100) \\
71 \cdot 5(29 \cdot 7-100) \\
64 \cdot 8(27 \cdot 2-90 \cdot 2)\end{array}$ \\
\hline $\begin{array}{l}\text { Control group } \\
3 \\
9 \\
12 \\
15\end{array}$ & $\begin{array}{l}99(90-100) \\
70 \cdot 5(30 \cdot 2-87 \cdot 6) \\
40 \cdot 8(36 \cdot 2-91 \cdot 4) \\
70 \cdot 2(56 \cdot 4-93 \cdot 4)\end{array}$ & $\begin{array}{c}100(87 \cdot 5-100) \\
50 \cdot 6(42 \cdot 9-92 \cdot 9) \\
79 \cdot 2(1 \cdot 7-100) \\
62 \cdot 5(37 \cdot 5-96)\end{array}$ & $\begin{array}{c}100(80-100) \\
55 \cdot 1(40-94 \cdot 9) \\
73 \cdot 3(25-86 \cdot 7) \\
60(55 \cdot 6-100)\end{array}$ & $\begin{array}{c}100(85 \cdot 7-100) \\
52 \cdot 2(5 \cdot 6-100) \\
60(28 \cdot 6-84 \cdot 6) \\
77 \cdot 8(28 \cdot 6-100)\end{array}$ & $\begin{array}{l}98 \cdot 3(97 \cdot 8-100) \\
69 \cdot 8(50 \cdot 6-90 \cdot 9) \\
63 \cdot 6(56-91 \cdot 6) \\
67 \cdot 3(58 \cdot 8-74 \cdot 7)\end{array}$ \\
\hline
\end{tabular}

Data of the 0-45 minute period are pooled together as there are no significant variations in the three 15 minute periods. ${ }^{\star} \mathrm{p}<0.04 v$ basal saline, $\mathrm{p}<0.05 v 0-15$ minute $\mathrm{HCl}$ period, $\mathrm{p}<0.03 v$ subsequent saline; ${ }^{\star \star} \mathrm{p}<0.04 v$ basal saline, $\mathrm{p}<0.05 v 0-15$ minute $\mathrm{HCl}$ period (medians and ranges). 


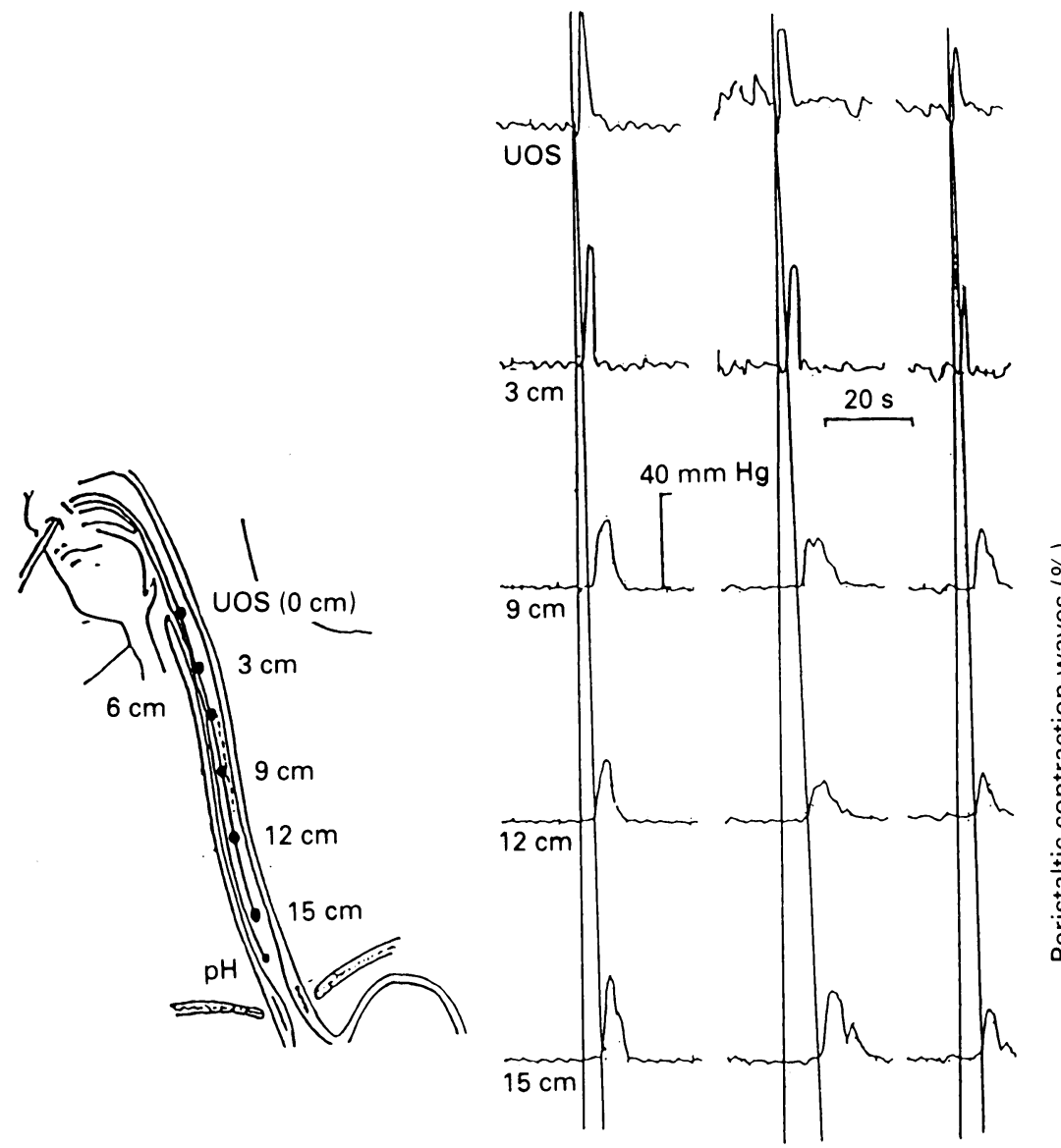

Figure 4: Three sequences of primary peristaltis during saline - $\mathrm{HCl}$ - saline infusion sequence. Note variations of duration, propagation velocity, and morphology of primary peristaltic contraction waves during $\mathrm{HCl}$ infusion (middle sequence).

acidification cannot be attributed to intraluminal distension because equal amounts of saline solution produced no effect; it cannot be excluded, however, that oesophageal acidification might induce an increase in the salivary secretion rate, which may ultimately affect duration and propagation velocity of primary peristalsis as a consequence of a larger volume of saliva swallowed with each deglutition. ${ }^{18}$ The lack of any difference between dry and wet swallows in the response pattern of primary peristalsis, however, does not support such an interpretation. The findings of this study strongly support the presence of acid sensitive 'receptor nerve fibres' within the oesophageal mucosa, which may contribute to the regulation of primary peristalsis. An afferent regulation through acid sensitive receptors nerve fibres has been hypothesised also to affect secondary peristalsis. ${ }^{13}$

Alternatively, afferent input is possibly caused by non-specific stimulation of nerve fibre endings secondary to acid induced mucosal damage, but this interpretation is unlikely because some of the acid related motor variations stopped immediately after intraluminal acidification had finished.

In this study, retrosternal symptoms were reported by 7,12 , and 12 subjects respectively, during the first, second, and third 15 minute period of acid infusion; retrosternal symptoms disappeared shortly after oesophageal acidification had ended, and only two subjects
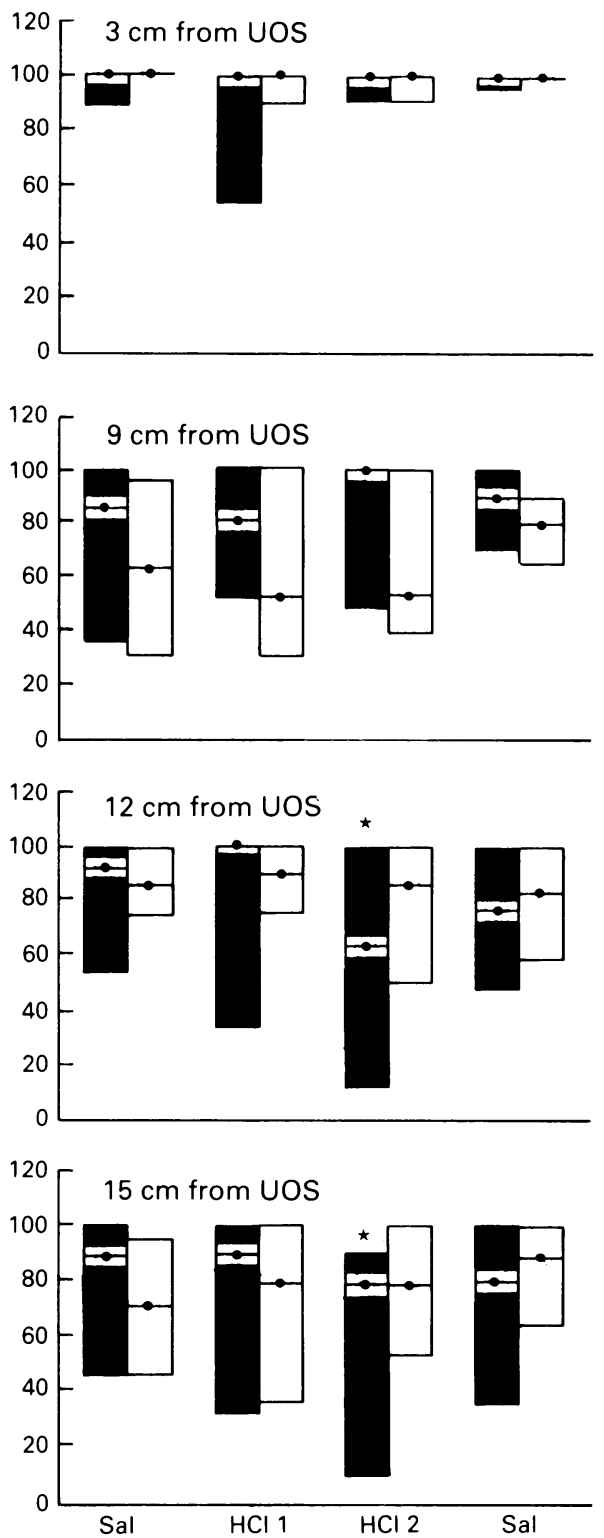

Figure 5: Percentage of single peaked primary peristaltic contraction waves after controlled wet swallows measured at $3,9,12$, and $15 \mathrm{~cm}$ from the upper oesophageal sphincter (UOS). $\mathrm{HCl} \mathrm{1,} \mathrm{HCl} \mathrm{2,} \mathrm{Sal,} \mathrm{and} \mathrm{Sal} \mathrm{show} \mathrm{the} \mathrm{series} \mathrm{of}$ controlled swallows during $\mathrm{HCl}$ and saline infusion, respectively. Values of saline infusions represent the two series of controlled swallows. Median values and interquartile ranges are illustrated. Filled columns: test patients: empty columns: control patients. ${ }^{\star} p<0 \cdot 04 \mathrm{v}$ basal saline infusion, $p<0.03 \mathrm{v} 1$ st series.

complained of symptoms during the control saline infusion. It is, therefore, impossible to analyse separately the possible role of acid induced symptoms and of oesophageal acidification in itself on the variations of the frequency of swallowing and of primary peristalsis.

In conclusion, this study shows that prolonged acidification of the oesophageal mucosa (in subjects with gastro-oesophageal reflux disease with no or minor degrees of endoscopic oesophagitis) causes an increase in the frequency of deglutitions, an increase in duration and amplitude, and also a decrease in the propagation velocity of primary peristalsis.

The effects of oesophageal acidification are independent from volume distension of the 
oesophagus, and this study strongly supports the presence of acid sensitive receptor nerve fibres in the oesophageal mucosa.

Whether oesophageal acidification affects swallowing and primary peristalsis directly through an oesophageal acid activated reflex or indirectly through acid induced symptoms, or both cannot be fully answered by this study.

This paper has been dedicated to Professor Salvatore Auricchio on the occasion of his 60th birthday.

1 Katz PO, Knuff TE, Benjamin SB, Castell DO. Abnormal esophageal pressures in reflux esophagitis: Cause or effect? Am f Gastroenterol 1986; 81: 744-6.

2 Skinner DB, Booth DJ. Assessment of distal esophageal function in patients with hiatal hernia and/or gastroesophageal reflux. Ann Surg 1970; 172: 627-37.

3 Garabedian $M$. Uses of esophageal manometry and acid perfusion in the study of gastroesophageal reflux and perfusion in the study of gastroesophageal reflux

4 Cohen S, Harris LD. The lower esophageal sphincter. Gastroenterology 1972; 63: 1066-73.

5 Thurer RL, Demeester TR, Johnson LF. The distal esophageal sphincter and its relationships to gastroesophageal reflux. $\mathcal{F}$ Surg Res 1974; 16: 418-23.

6 Ahtaridis G, Snape WJ, Cohen S. Lower esophagea sphincter pressure as an index of gastroesophageal acid reflux. Dig Dis Sci 1981; 26: 993-8.

7 Kahrilas PJ, Dodds WJ, Hogan WJ, Kern M, Arndorfer RC, Reece A. Esophageal peristaltic dysfunction in peptic esophagitis. Gastroenterology 1986; 91: 897-904.
8 Campo S, Traube M. Lower esophageal sphincter dysfunction in diffuse esophageal spasm. Am $\mathcal{J}$ Gastroenterol 1989; 84: 928-32.

9 Richter SE, Johns DN, Wu WC, Castell DO. Are esophageal motility abnormalities produced during the intraesophageal acid perfusion test? $\mathcal{F} A M A$ 1985; 253 1914-7.

10 Siegel CI, Hendrix TR. Esophageal motor abnormalities induced by acid perfusion in patients with heartburn. f Clin Invest 1963; 42: 686-95.

11 Helm JF, Massey BT, Martin CJ, Dodds WJ, Hogan WJ, Arndorfer RC. Oesophageal acidification does not increase lower oesophageal sphincter pressure. Gut 1990; 31: $266-9$.

12 Madsen $\mathrm{T}$, Wallin L, Boesby S, Hojkjaer Larsen V. Spontaneous peristaltic activity in esophagus after imitated acid gastroesophageal reflux. A study in normal subjects. Scand f Gastroenterol 1982; 17: 811-5.

13 Corazziari E, Pozzessere C, Dani S, Anzini F, Torsoli A Intraluminal $\mathrm{pH}$ and esophageal motility. Gastroenterology 1978; 75: 275-7.

14 Corazziari E, Materia E, Pozzessere C, Anzini F, Torsoli A. Intraluminal $\mathrm{pH}$ and oesophageal motility in patients with gastroesophageal reflux. Digestion 1986; 35: 151-7.

15 Burns TW, Venturatos SG. Esophageal motor function and response to acid perfusion in patients with sympto-

16 Kjellen G, Tibbling L. Osophageal motility during acid provoked heartburn and chest pain. Scand $¥$ Gastroenterol provoked heartburn

17 De Caestecker JS, Pryde A, Heading RC. Comparison of intravenous edrophonium and oesophageal acid perfusion during oesophageal manometry in patients with noncardiac chest pain. Gut 1988; 29: 1029-34.

18 Hollis JB, Castell DO. Effect of dry swallows and wet swallows of different volumes on oesophageal peristalsis. f Appl Physiol 1975; 38: 1161-4. 